\title{
Volatilizable Biogenic Organic Compounds (VBOCs) with two dimensional Gas Chromatography-Time of Flight Mass Spectrometry (GC x GC-TOFMS): sampling methods, VBOC complexity, and chromatographic retention data
}

\author{
J. F. Pankow ${ }^{1,2}$, W. Luo ${ }^{1,2}$, A. N. Melnychenko ${ }^{3}$, K. C. Barsanti ${ }^{2}$, L. M. Isabelle ${ }^{1,2}$, C. Chen $^{1}$, A. B. Guenther ${ }^{4}$, and \\ T. N. Rosenstiel ${ }^{3}$ \\ ${ }^{1}$ Department of Chemistry, Portland State University, Portland, OR 97207, USA \\ ${ }^{2}$ Department of Civil \& Environmental Engineering, Portland State University, Portland, OR 97207, USA \\ ${ }^{3}$ Department of Biology, Portland State University, Portland, OR 97207, USA \\ ${ }^{4}$ Atmospheric Chemistry Division, National Center for Atmospheric Research, Boulder, CO 80305, USA
}

Correspondence to: J. F. Pankow (pankowj@pdx.edu)

Received: 13 May 2011 - Published in Atmos. Meas. Tech. Discuss.: 10 June 2011

Revised: 9 December 2011 - Accepted: 4 January 2012 - Published: 14 February 2012

\begin{abstract}
Two dimensional gas chromatography $(\mathrm{GC} \times \mathrm{GC})$ with detection by time-of-flight mass spectrometry (TOFMS) was applied in the rapid analysis of air samples containing highly complex mixtures of volatilizable biogenic organic compounds (VBOCs). VBOC analytical methodologies are briefly reviewed, and optimal conditions are discussed for sampling with both adsorption/thermal desorption (ATD) cartridges and solid-phase microextraction (SPME) fibers. Air samples containing VBOC emissions from leaves of two tree species (Cedrus atlantica and Calycolpus moritzianus) were obtained by both ATD and SPME. The optimized gas chromatographic conditions utilized a $45 \mathrm{~m}, 0.25 \mathrm{~mm}$ I.D. low-polarity primary column (DB-VRX, $1.4 \mu \mathrm{m}$ film) and a $1.5 \mathrm{~m}, 0.25 \mathrm{~mm}$ I.D. polar secondary column (Stabilwax ${ }^{\mathrm{TM}}, 0.25 \mu \mathrm{m}$ film). Excellent separation was achieved in a 36 min temperature programmed $\mathrm{GC} \times \mathrm{GC}$ chromatogram. Thousands of VBOC peaks were present in the sample chromatograms; hundreds of tentative identifications by NIST mass spectral matching are provided. Very few of the tentatively identified compounds are currently available as authentic standards. Minimum detection limit values for a 51 ATD sample were $3.5 \mathrm{pptv}\left(10 \mathrm{ng} \mathrm{m}^{-3}\right)$ for isoprene, methyl vinyl ketone, and methacrolein, and $\sim 1.5 \mathrm{pptv}$ $\left(\sim 10 \mathrm{ng} \mathrm{m}^{-3}\right)$ for monoterpenes and sesquiterpenes. Kovatstype chromatographic retention index values on the primary column and relative retention time values on the secondary
\end{abstract}

column are provided for 21 standard compounds and for 417 tentatively identified VBOCs. 19 of the 21 authentic standard compounds were found in one of the Cedrus atlantica SPME samples. In addition, easily quantifiable levels of at least 13 sesquiterpenes were found in an ATD sample obtained from a branch enclosure of Calycolpus moritzianus. Overall, the results obtained via GC $\times$ GC-TOFMS highlight an extreme, and largely uncharacterized diversity of VBOCs, consistent with the hypothesis that sesquiterpenes and other compounds beyond the current list of typically determined VBOC analytes may well be important contributors to global atmospheric levels of organic particulate matter.

\section{Introduction}

Organic compounds volatilize to the atmosphere from both anthropogenic and biogenic sources. Anthropogenic emissions of non-methane volatile organic compounds (VOCs) have been estimated at 110 to $150 \mathrm{TgC} \mathrm{yr}^{-1}$ (Muller, 1992; Piccot et al., 1992). In contrast, the global input to the atmosphere of non-methane biogenic volatile organic compounds

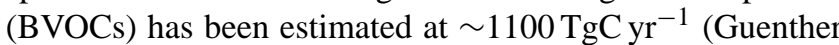
et al., 1995), much of that amount being plant related. The non-methane BVOCs are: (1) important in the geochemical cycling of carbon (Guenther, 2002); (2) have significant

Published by Copernicus Publications on behalf of the European Geosciences Union. 
effects on tropospheric ozone levels (Williams et al., 1997; Starn et al., 1998); (3) affect hydroxyl radical concentrations (Tan et al., 2001; Lelieveld et al., 2008) and thus the lifetimes of ozone-depleting and greenhouse gases (Kaplan et al., 2006); and (4) oxidized in the atmosphere to products that can condense (Haagen-Smit, 1952) and thereby form atmospheric organic particulate matter (OPM) that can affect the radiative and cloud nucleation properties of atmospheric particles (Goldstein et al., 2009; Pöschl et al., 2010).

European Union Directive 1999/13/EC defines a VOC as any organic compound having a vapor pressure of $\geq 10^{-2} \mathrm{kPa}$ $\left(10^{-4} \mathrm{~atm}\right)$ at $293.15 \mathrm{~K}$. Isoprene as a pure liquid at this temperature has a vapor pressure of $p_{\mathrm{L}}^{\mathrm{o}}=70 \mathrm{kPa}(0.7 \mathrm{~atm})$. A semivolatile organic compound (SVOC) has been defined as a compound with a $p_{\mathrm{L}}^{\mathrm{o}}$ value in the range from $10^{-2} \mathrm{kPa}$ $\left(10^{-4} \mathrm{~atm}\right)$ down to $10^{-9} \mathrm{kPa}\left(10^{-11} \mathrm{~atm}\right)$ (Bidleman, 1988). By definition, an SVOC has significant affinity for condensed phases, yet is sufficiently volatile that it can partition significantly to the atmosphere, particularly when other mechanisms (e.g., oxidation) continually remove the compound from the gas phase and thus maintain the driving force for volatilization. De Gouw et al. (2011) have reported observations that suggest that SVOCs can evaporate from spilled crude oil, be oxidized in the atmosphere to lower vapor pressure compounds, and thereby lead to formation of atmospheric OPM. At $p_{\mathrm{L}}^{\mathrm{o}} \approx 10^{-3} \mathrm{kPa}\left(10^{-5} \mathrm{~atm}\right)$ at $293 \mathrm{~K}$, sesquiterpenes (e.g., farnesene) are relatively volatile SVOCs, and are of significant interest here for their contribution to both gas- and particle-phase processes. Therefore, in place of the term BVOCs, we use the term volatilizable biogenic organic compounds (VBOCs) to refer to the full span of biogenic compounds of interest here. (The VBOC group is not intended here to include methane.)

Plants release VBOCs simply because in plant tissues these compounds tend to be lost to the surrounding environment by diffusive transport mechanisms; accelerated loss can occur because of mechanical/herbivore wounding (e.g., Heiden et al., 2003). Of particular interest is the fact that increased emissions of certain VBOCs are associated with plants experiencing environmental stress (e.g., Heiden et al., 2003). Stress indicator compounds include ocimene, farnesene, methyl salicylate, salicylic acid, jasmonic acid, and a group of $\mathrm{C}_{6}$ aldehydes, alcohols, and esters referred to as "green-leaf volatiles" (Heil and Ton, 2008; Kännaste et al., 2008; Staudt and Bertin; 1998).

Overall, VBOCs are highly diverse and include: (1) numerous terpenes including isoprene $\left(\mathrm{C}_{5} \mathrm{H}_{8}\right)$ which is a hemiterpene, monoterpenes $\left(\mathrm{C}_{10} \mathrm{H}_{16}\right)$, sesquiterpenes $\left(\mathrm{C}_{15} \mathrm{H}_{24}\right)$, and diterpenes $\left(\mathrm{C}_{20} \mathrm{H}_{32}\right)$; (2) terpenes that are functionalized (e.g, oxidized) in numerous ways and at a variety of positions; (3) alkanes and alkenes; (4) alkyl aldehydes and ketones; (5) alkyl alcohols, ethers, acids, and esters; and 6) chiral variants such as $( \pm)-\alpha$-pinene, $( \pm)-\beta$ pinene, and $( \pm$ )-limonene (Williams et al., 2007; Yassaa et al., 2010). The complexity of the VBOC group is therefore due both to the variety of chemical sub-classes represented, and to the substantial numbers of compounds in many of the sub-classes. Another complicating factor is that the reactivities of individual VBOCs vary widely. With regard to functionalized compounds, the term VBOC, as used here, explicitly includes early oxidation products of plant-produced compounds (caryophyllene oxide is an example of such an oxidation product).

The chemical variety, numbers, and reactivities of VBOCs have posed considerable challenges in efforts designed to develop quantitative understandings of important processes governing the VBOCs. First, large uncertainties remain regarding simply the overall magnitude of the total annual mass emissions of VBOCs and whether unidentified or undetected compounds contribute significantly to those emissions (e.g., Goldstein and Galbally, 2007). Even when the list of VBOCs considered is relatively "comprehensive" (e.g., isoprene, $\alpha$ $/ \beta$-pinene, $\alpha$-phellandrene, camphene, $\Delta^{3}$-carene, limonene, myrcene, $\alpha-/ \gamma$-terpinene, terpinolene, linalool, nopinone, methyl-chavicol, $\alpha$-bergamotene, $\beta$-caryophyllene, $\alpha-/ \beta$ farnesene, longifolene), the measured fluxes and atmospheric concentrations do not appear to account for total VBOC mass emissions. For example, measured fluxes have not always been consistent with observed levels of $\mathrm{OH}$ reactivity ( $\mathrm{Di}$ Carlo et al., 2004), observed $\mathrm{O}_{3}$ fluxes (Goldstein et al., 2004), or emissions data from co-located enclosure samples (Goldstein et al., 2004; Bouvier-Brown et al., 2009a). Moreover, observations of higher than expected secondary organic aerosol levels have been cited as evidence of "missing" VBOCs (e.g., Goldstein and Gallbally, 2007). There are numerous difficulties that complicate the acquisition of accurate VBOC emission estimates. First, mass emission estimates are difficult for reactive terpenoids, even in locations where the emission rates are relatively high (Bouvier-Brown et al., 2009a,b; Ortega et al., 2007). Second, large uncertainties remain regarding the variabilities in VBOC emissions by plant species, geographic location, and season (e.g., Helmig et al., 2007). For example, annual emissions in the US of isoprene and a number of monoterpenes may be changing by amounts and for reasons that are not adequately understood (Purves et al., 2004), and the responses of VBOC emissions to changing climate parameters remain highly uncertain (Rosenstiel et al., 2003; Guenther et al., 2006; Chen et al., 2009; Penuelas and Staudt, 2010). Third, almost nothing is known concerning either the relative importance of chiral variants (e.g. (+)- vs. (-)- $\alpha$-pinene, (+)- vs. (-)- $\beta$-pinene, etc.), or how much important biogeochemical information is held within chiral patterns of VBOC emissions (Williams et al., 2007; Yassaa et al., 2010). Overall, despite the fact that many BVOC emission studies currently appear each year in the scientific literature, most have targeted only a few compounds as analytes. In contrast, investigators making the effort to look for other compounds (e.g., Jardine et al., 2010) have found a wide range of VBOCs. 
Given the significant impact of VBOC emissions on biosphere-atmosphere interactions and air chemistry, there is a great need for development and application of new analytical methodologies capable of characterizing the complex nature of VBOC emissions. Development of new methodologies can be obtained by: (1) application of suitable sample collection methods; (2) application of high-separation gas chromatography (GC) methods that can adequately address VBOC complexity; and (3) accumulation of GC retention index information based on as many authentic standard compounds as possible (many VBOCs of interest are not easily obtained in pure form). Here we describe the collection, tentative identification and determination, and chromatographic characterization of VBOCs in highly complex samples using two-dimensional gas chromatography/timeof-flight mass spectrometry (GC $\times$ GC/TOFMS), the latter being the most powerful separation+detection methodology currently available for VBOCs. We preface the description of the laboratory measurements with a brief review of available methods for sampling and analysis.

\section{Available sampling and analysis methods}

\subsection{Determination with field-deployed instrumentation}

Analytical instruments have often been deployed to the field in studies of plant-derived VBOCs in ambient air and as emanating from plants within experimental enclosures. Though often costly and logistically difficult, field deployment of instruments is advantageous when plant emissions and ambient concentrations are subject to short time variations: VBOCs that are moderately-to-highly reactive are of particular interest in this regard. Field-deployed analytical approaches are discussed in a recent review (Ortega and Helmig, 2008) and include: (1) chemiluminescence for detection of isoprene (Guenther et al., 1996; Singsaas and Sharkey, 2000); (2) proton transfer reaction mass spectrometry (PTR-MS) for the direct simultaneous detection of multiple compounds (Karl et al., 2001; Bamberger et al., 2010; Mielke et al., 2010); (3) solid phase microextraction (SPME) fiber collection of analytes followed by thermal desorption to a field GC instrument; and (4) adsorption/thermal desorption (ATD) cartridge sampling of a known air volume (e.g., 1-10 l) followed by thermal desorption of the analytes to a field GC instrument. PTR-MS has been employed when VBOC concentrations are subject to high temporal variability (e.g., minutes) as in studies of forest air (e.g., Mielke et al., 2010), fluxes by eddy covariance measurements (e.g., Karl et al., 2001; Bamberger et al., 2010), and emission processes in dynamic enclosure studies (e.g., Grabmer et al., 2006; Bouvier-Brown et al., 2007). Good agreement has been obtained for total sesquiterpenes in field-deployed PTR-MS vs. SPME (Bouvier-Brown et al., 2007). (PTR-MS cannot distinguish different structural isomers because it only measures molecular masses, e.g., cannot distinguish individual monterpenes, individual sesquiterpenes, etc.)

\subsection{Determination in the laboratory}

ATD cartridges are easily transported to and from the field, and provide a simple, sensitive, and quantitative approach for determining a wide range of VOCs at ambient atmospheric levels (Pankow et al., 1998, 2003). Laboratory-based ATD determinations of VBOCs in field samples have utilized GC/FID, GC/MS, and GC $\times$ GC-TOFMS (Saxton et al., 2007). (FID = flame ionization detector.) Several considerations are important in the implementation of ATD with VBOCs. First, losses of reactive VBOCs may need to be prevented by removal of oxidants, particularly ozone, prior to passage of the sample air through the cartridge (Cao and Hewitt, 1994; Calogirou et al., 1996). Numerous different ozone removal methods have been used (Helmig, 1997; Fick et al., 2001; Pollmann et al., 2005). These have involved sodium thiosulfate on filters (Helmig et al., 1998), potassium iodide on glass wool or filters (Helmig and Greenberg, 1994), manganese dioxide on porous nets or copper screens (Hoffmann, 1995; Calogirou et al., 1996), and titration of ozone with nitrogen monoxide (Komenda et al., 2003). Second, because atmospheric concentrations decrease strongly with decreasing VBOC volatility (viz., vapor pressure), if the goal is the simultaneous quantitation of a wide range of compounds, it may be necessary to use a large sample volume. That choice usually leads to the need for multiple sorbents in the bed: weaker sorbent first, then the stronger sorbent. The low $p_{\mathrm{L}}^{\mathrm{o}}$ compounds are retained on the weaker sorbent, and the higher $p_{\mathrm{L}}^{\mathrm{o}}$ compounds pass onto and are retained by the stronger sorbent. After sampling, the thermal desorption flow occurs in a backflush direction so that the lower $p_{\mathrm{L}}^{\mathrm{o}}$ compounds are not exposed to the stronger sorbent. Given the large dynamic range in concentration usually accompanying such samples, currently it can be helpful to employ a unit such as the TurboMatrix 650 ATD (PerkinElmer, Waltham, MA) for the thermal desorption. With the ATD, the desorption flow can be divided so that part (e.g., $30 \%$ ) goes to the $\mathrm{GC}$ and the remainder goes to a pre-cleaned cartridge to be held for a possible second GC run. For the first GC run, the injector split ratio might be 10:1. If the injector split ratio in the second GC run is lower (e.g., 5:1), then the method sensitivity in the second run can be higher than in the first run $($ e.g. $(70 / 30)(0.2 / 0.1) \approx 4 \times)$. This can allow less abundant compounds to become quantifiable, though some of the early-eluting compounds may then be overloaded.

Common ATD adsorbents for VBOCs include the porous organic polymer Tenax ${ }^{\mathrm{TM}}$ TA and several more strongly sorbing carbon-based materials (Table 1). Attractive characteristics of these adsorbents are their good abilities to reversibly sorb analytes, low water affinities (i.e., low breakthrough volume (BV) values for water), and complementary sorption strengths (Dettmer and Engewald, 2002; Arnts et 
Table 1. Properties of adsorbent materials used in collection and analysis of volatilizable biogenic organic compounds (VBOCs) using adsorption/thermal desorption (ATD).

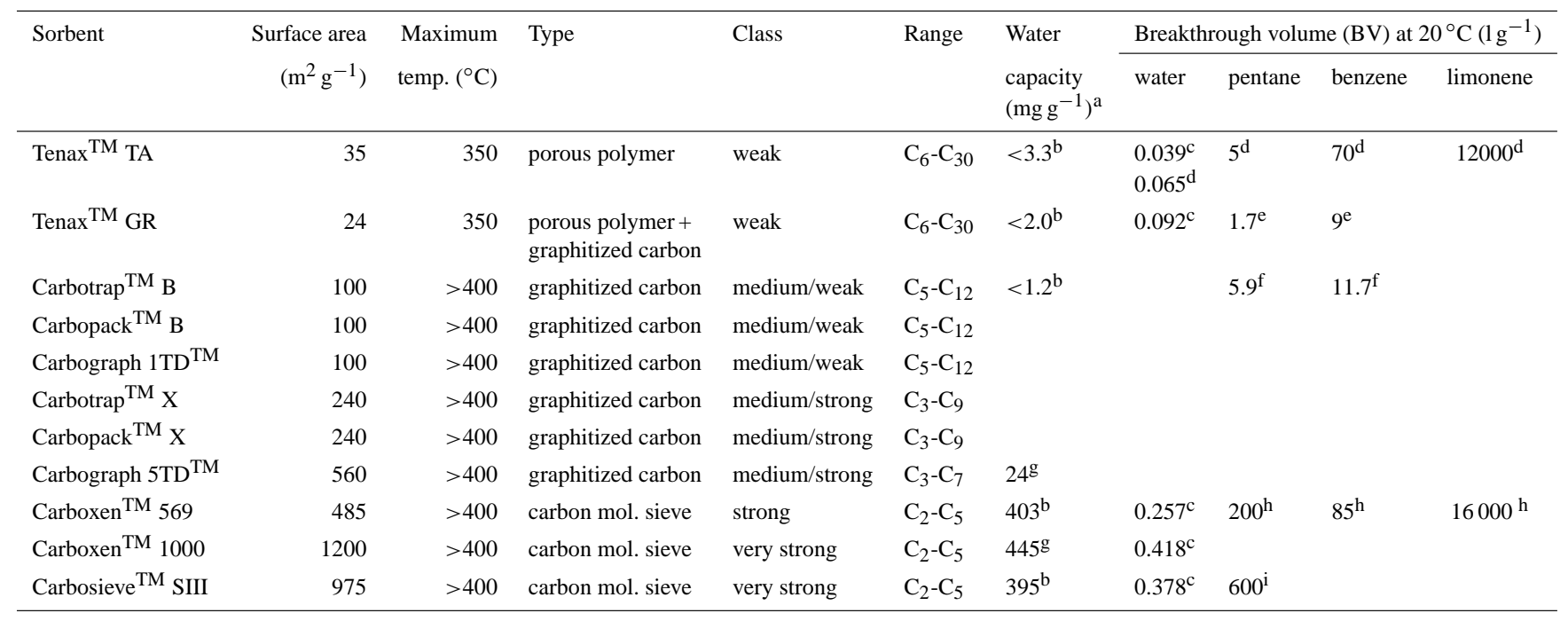

a Water sorption capacities at $20^{\circ} \mathrm{C}$ and relative humidity $=95-100 \%$.

b Helmig, D. and Vierling, L.: Water adsorption capacity of the solid adsorbents Tenax TA, Tenax GR, Carbotrap, Carbotrap C, Carbosieve SIII, and Carboxen 569 and water management techniques for the atmospheric sampling of volatile organic trace gases, Anal. Chem., 67, 4380-4386, 1995.

${ }^{\mathrm{c}}$ Dettmer, K. and Engewald, W.: Adsorbent materials commonly used in air analysis for adsorptive enrichment and thermal desorption of volatile organic compounds, Anal. Bioanal. Chem., 373, 490-500, 2002.

d http://www.sisweb.com/index/referenc/tenaxta.htm, last access: 6 March 2011.

e http://www.sisweb.com/index/referenc/tenaxgr.htm, last access: 6 March 2011.

${ }^{\mathrm{f}}$ http://www.sigmaaldrich.com/etc/medialib/docs/Supelco/Bulletin/4501.Par.0001.File.tmp/4501.pdf, last access: 6 March 2011.

g Fastyn, P., Kornacki, W., Gierczak, T., Gawłowski, J., and Niedzielski, J.: Adsorption of water vapour from humid air by selected carbon adsorbents, J. Chromatogr. A, 1078, 7-12, 2005.

${ }^{\mathrm{h}}$ http://www.sisweb.com/index/referenc/carbo569.htm, last access: 6 March 2011.

${ }^{\mathrm{i}}$ http://www.sisweb.com/index/referenc/carbs111.htm, last access: 6 March 2011.

al., 2010). BV values for monoterpenes on Tenax ${ }^{\mathrm{TM}} \mathrm{TA}$ are high (Table 1) so that for sample volumes of a few liters and $\sim 100 \mathrm{mg}$ of Tenax ${ }^{\mathrm{TM}} \mathrm{TA}$, monoterpenes are quantitatively retained. That is not the case for isoprene and other volatile compounds, retention of which requires the additional presence of a carbon-based sorbent. Many current ATD applications utilize 0.25 inch O.D. $\times 3.5$ inch cartridges packed with $\sim 100 \mathrm{mg}$ of Tenax ${ }^{\mathrm{TM}} \mathrm{TA}$ followed by $\sim 100 \mathrm{mg}$ of either Carbotrap ${ }^{\mathrm{TM}}$ B or Carbograph ${ }^{\mathrm{TM}}$ 1TD (Komenda et al., 2001; Sartin et al., 2001; Hakola et al., 2006; Helmig et al., 2007; Ortega and Helmig, 2008; Haapanala et al., 2009; Geron and Arnts, 2010). The Tenax ${ }^{\mathrm{TM}}$ TA prevents compounds like the monoterpenes from substantively reaching the carbon-based sorbent whereon they would not only be strongly retained but also possibly chemically altered. Significant interconversion of several monoterpenes has been reported on Carbotrap ${ }^{\mathrm{TM}} 200$ and Carbotrap ${ }^{\mathrm{TM}} 300$ (Greenberg et al., 1999a). Similar results have been reported by Cao and Hewitt (1993).
Super-Q and HayeSep-Q adsorbent cartridges (Papiez et al., 2009; Ormeno et al., 2010; Heuskin et al., 2012) and SPME fibers (Bouvier-Brown et al., 2009b) provide alternatives to ATD cartridges. SPME, however, can be considerably less sensitive than ATD (as with highly volatile analytes that are weakly sorbed and/or with low volatility compounds at low concentrations), does not provide as much overall sample stability (Bouvier-Brown et al., 2007; Baker and Sinnott, 2009), and is labor intensive to calibrate in quantitative applications. Nevertheless, SPME becomes exceedingly attractive for its convenience when the analyte concentrations are high, the work is proceeding in/near a laboratory, and/or the desired determinations are only qualitative or semi-quantitative in nature. SPME has been used in laboratory-based measurements with GC-FID to determine isoprene emission rates from enclosed tree seedling branches (Tsui et al., 2009), and with GC/FID, GC/MS and 1001 Tedlar bags to measure sesquiterpene emissions from whole trees (Pinus sabiniana and Pinus ponderosa) (Baker and Sinnott, 2009). Super-Q and HayeSep-Q are most appropriate 
for lower-volatility VBOCs (e.g., mono- and sesquiterpenes); samples typically are solvent extracted an analyzed using GC/MS (Papiez et al., 2009; Ormeno et al., 2010; Heuskin et al., 2012).

"Whole-air" sampling with canisters or bags provides an alternative to ATD cartridges and SPME fibers as a means to collect and transport sample analytes to a conventional laboratory for analysis. Whole air in a canister or bag can be aliquotted with a sample loop, cryofocused (e.g., at $-150^{\circ} \mathrm{C}$ on a trap containing 60/80 mesh glass beads as in method TO-14; US EPA, 1999a), sampled using ATD (Pressley et al., 2004) or SPME (Bouvier-Brown et al., 2007), or cryofocussed directly on the GC column (Pankow, 1986). For canisters, inert internal surfaces are important, and both Summa-polished ${ }^{\mathrm{TM}}$ stainless steel and Silcosteel ${ }^{\mathrm{TM}}$ canisters are used (US EPA, 1999a,b). However, canisters are still subject to losses at high humidity (Batterman et al., 1998), and are costly and complicated to clean. Teflon bags suffer from blank problems, frequently leak, and are difficult to clean after use (Greenberg et al., 1999a); Tedlar bags are subject to similar problems. Available data indicate that many analytes are more stable when stored on ATD cartridges than in bags, especially when oxidant species are present in the sample air. Evidence of losses in Teflon bags for methacrolein, methyl vinyl ketone, and $\alpha$-pinene have been reported (Greenberg et al., 1999a). A summary of minimum detection limit (MDL) values for VBOCs by various methodologies is provided in Table 2.

\subsection{GC $\times$ GC-TOFMS}

Applications of GC $\times$ GC usually utilize a primary column with either a non-polar or low-polarity stationary phase. Coelution of some peaks from the primary column is inevitable with highly complex samples. With GC $\times$ GC (aka 2D GC), periodic slices of effluent from the primary column are individually: (1) cryofocused at the end of the column; then (2) thermally desorbed to a secondary column with a more polar stationary phase. Separation of compounds that coexist in a given slice can be accomplished on the secondary column if the compounds differ in polarities and/or polarizabilities. GC $\times$ GC-TOFMS has been applied with success in the analysis of diesel fuel (Arey et al., 2005), weathered petroleum (Frysinger et al., 2003), urban aerosol particulate matter (Hamilton et al., 2004), tobacco smoke particulate matter (Cochran, 2008), and tissue extracts (Welthagen et al., 2005). GC $\times$ GC chromatographic retention index data have been tabulated for diesel fuel hydrocarbons (Arey et al., 2005), but not for VBOCs.

The varying polarizabilty/polarity characteristics of the VBOCs are imparted by varying numbers of rings, double bonds, and polar functionalizations. $\mathrm{GC} \times \mathrm{GC}$ with a lesspolar primary column and a more-polar secondary column is well suited for separating VBOC mixtures. $\mathrm{GC} \times \mathrm{GC}$ TOFMS has been used to determine VBOCs in ATD samples of forest canopy air and air from branch and leaf enclosures (Saxton et al., 2007). Quantitative measurements were reported for isoprene, $\alpha$-pinene, $\beta$-pinene, camphene and limonene, as were relative peak intensities for 11 tentatively identified compounds (Saxton et al., 2007).

\section{Experimental}

\subsection{Chemicals and standard mixtures}

21 VBOC chemicals ( $\geq 95 \%$ pure) were obtained from Sigma-Aldrich (St. Louis, MO) (isoprene, $\alpha$-pinene, camphene, myrcene, $\beta$-pinene, $\alpha$-phellandrene, $\Delta^{3}$-carene, limonene, terpinolene, $p$-cymene, nopinone, linalool, 4terpinenol, terpineol, eucalyptol, camphor, estragole (methyl chavicol), $\alpha$-cedrene, caryophyllene, aromadendrene, and $\alpha$-humulene). Optimally, the list of standard compounds would have included many tens of $\mathrm{C}_{10}$-and-higher VBOCs. Unfortunately, authentic standard materials are not readily available for the vast majority of such compounds, and even just having doubled the number of standard compounds would have required use of multi-component "essential oils", with concomitant prior quantitation of the VBOC components of interest. Such efforts are underway in our laboratories, but were not applied in this study. Standard mixes of the 21 VBOCs in methanol were prepared at percomponent concentrations from $0.5 \mathrm{ng}_{\mu} \mathrm{l}^{-1}$ to $20 \mathrm{ng} \mu^{-1}$. A gas standard containing four internal standard (IS) compounds (fluorobenzene, toluene- $\mathrm{d}_{8}$, 4-bromofluorobenzene, and 1,2-dichlorobenzene- $\mathrm{d}_{4}$ ) at $80 \mathrm{ng} \mathrm{ml}^{-1}$ per component was prepared in a stainless steel canister as described elsewhere (Pankow et al., 1998). The IS compounds were used: (1) to monitor the overall effectiveness of the thermal transfer from each sampling cartridge to the primary GC column; (2) as clearly identifiable (e.g., non-biogenic) retention time markers; and (3) a source of constant reference signals during the determination of the MDL values reported here, as based on analyses carried out at varying on-cartridge levels of isoprene and the other target analytes. Isotopically-labelled surrogate standard compounds were not necessary in this study.

\subsection{ATD cartridges - NCAR preparation and procedures for field sampling}

Field samples discussed here were collected by the Biosphere-Atmosphere Interactions Group of the National Center for Atmospheric Research (NCAR). Details regarding sample collection are available (Greenberg et al., 1999a,b, 2004). Briefly, samples were obtained using stainless steel, 0.25 inch O.D. $\times 3.5$ inch, dual sorbent cartridges (Tenax $^{\mathrm{TM}}$ TA plus Carbotrap ${ }^{\mathrm{TM}} \mathrm{B}$, or Tenax ${ }^{\mathrm{TM}}$ GR plus Carbograph $^{\mathrm{TM}}$ ). Prior to sampling, cartridges were cleaned by heating for $8 \mathrm{~h}$ at $275^{\circ} \mathrm{C}$ with a $50 \mathrm{ml} \mathrm{s}^{-1}$ flow of ultrahigh purity $\mathrm{N}_{2}$ gas. Clean cartridges were capped and stored at $10^{\circ} \mathrm{C}$ until used. The apparatus consisted of an $\mathrm{O}_{3}$ trap 


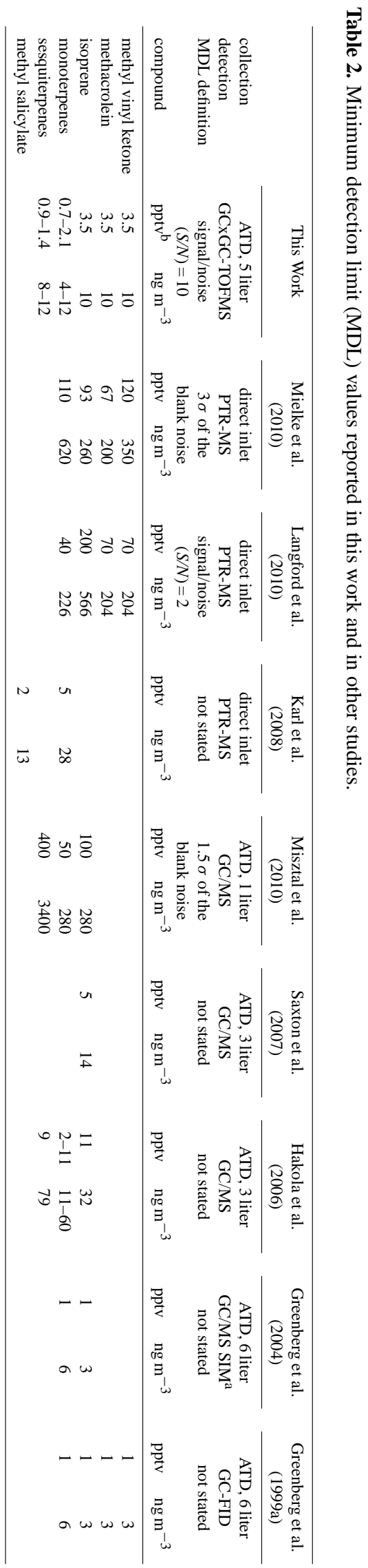


(KI impregnated filter), the sample cartridge, and a flowcontrolled pump. Samples were collected at a flow rate of $200 \mathrm{~cm}^{3} \mathrm{~min}^{-1}$ for $30 \mathrm{~min}$. After sampling, cartridges were sealed, shipped at ambient temperatures back to the laboratory (maximum 1 week shipping time), then maintained at $10^{\circ} \mathrm{C}$ until analyzed. After four weeks at ambient temperatures, losses were $<10 \%$ for $\mathrm{C}_{3}$ to $\mathrm{C}_{6}$ compounds of interest (Greenberg et al., 1999a).

\subsection{ATD cartridges and SPME fibers - PSU preparation and procedures for samples obtained in the laboratory}

In laboratory ATD sampling of air from vials holding plant materials, each glass cartridge contained $100 \mathrm{mg}$ of Tenax ${ }^{\mathrm{TM}}$ TA plus $120 \mathrm{mg}$ of Carbotrap ${ }^{\mathrm{TM}} \mathrm{B}$. (Prior to packing, $5 \mathrm{~g}$ of Tenax ${ }^{\mathrm{TM}}$ TA was placed in a glass column and cleaned with a $250 \mathrm{ml}$ flow of 50/50 (v/v) acetone/hexane.) After packing, each cartridge was conditioned for $1 \mathrm{~h}$ at $300^{\circ} \mathrm{C}$ with $100 \mathrm{ml} \mathrm{min}^{-1}$ of He gas (precleaned using a U-shaped hydrocarbon trap in liquid $\mathrm{N}_{2}$ ). Each conditioned cartridge was sealed with brass Swagelok endcaps that had been precleaned by rinsing in 50:50 acetone/hexane followed by baking $\left(90 \mathrm{~min}, 150^{\circ} \mathrm{C}\right)$. The endcaps were fitted with Teflon ferrules precleaned with methanol and water. Each sealed cartridge was stored in a clean glass culture tube. Other cartridge handling procedures were as described elsewhere (Pankow et al., 1998). The SPME assembly was obtained from Sigma-Aldrich (St. Louis, MO) and utilized with fibers coated with polydimethylsiloxane/divinylbenzene (coating thickness $65 \mu \mathrm{m}$ ). Prior to sampling, the fibers were cleaned for $30 \mathrm{~min}$ at $250^{\circ} \mathrm{C}$ in a GC injector through which precleaned He was flowing at $50 \mathrm{ml} \mathrm{min}^{-1}$.

Plant material samples (needles) were collected from a mature ( $>20 \mathrm{~m}$ ) Cedrus atlantica tree located on the Portland State University (PSU) campus. Three samples of 0.5 to $1.0 \mathrm{~g}$ each were collected in October-December (2010) at $\sim 2 \mathrm{~m}$ above ground level from tips of branches with full-sun exposure. Each sample was placed in an individual precleaned $40 \mathrm{ml}$ clear glass vial fitted with a Teflon-lined septum. After 60 min of exposure at $\sim 20^{\circ} \mathrm{C}$ to a cool light source (airported halogen lamp, 300 watt, $1000 \mu$ mol photons $\mathrm{m}^{-2} \mathrm{~s}^{-1}$ ), sampling by SPME or ATD occurred as air was passing through the vials (Fig. 1). The air was either cleaned laboratory air (CLA) or uncleaned laboratory air (ULA). Cleaning of the air was accomplished using a Perkin-Elmer hydrocarbon trap. Use of the uncleaned laboratory air greatly increased the complexity of the samples and thereby facilitated a more rigorous test of the ability of $\mathrm{GC} \times \mathrm{GC}$ TOFMS to adequately separate and detect VBOCs in the presence of myriad other VOCs. ATD air sampling occurred at $60 \mathrm{ml} \mathrm{min}^{-1}$ for $60 \mathrm{~min}$ (3.61). ATD cartridges were either analyzed immediately or within three weeks after storage at $-15^{\circ} \mathrm{C}$; standard cartridges analyzed after three weeks at $-15^{\circ} \mathrm{C}$ showed no evidence of analyte loss. Each SPME

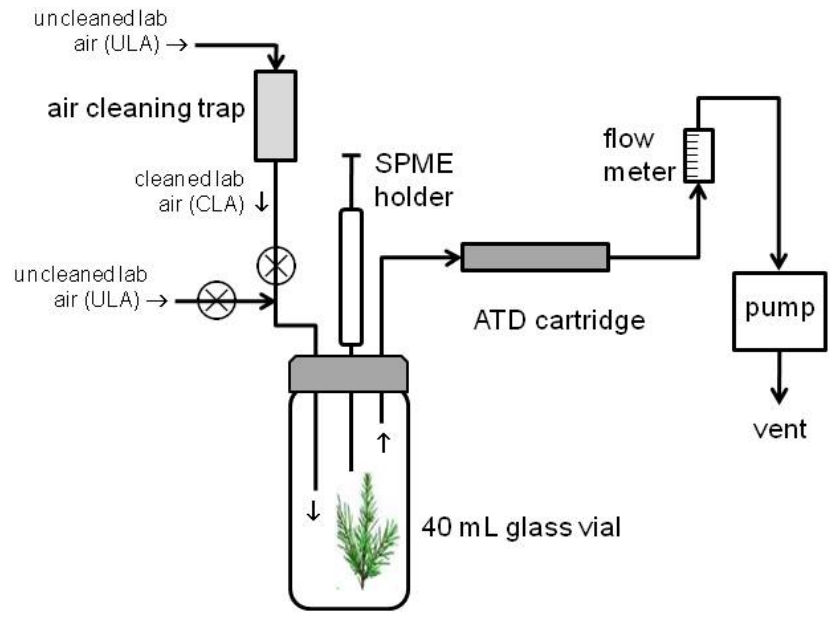

Fig. 1. Diagram of system used to obtain SPME and ATD samples of VBOCs in the laboratory with samples of Cedrus atlantica.

sampling event was carried out for a specific time period (10 to $60 \mathrm{~min}$ ) under "dynamic" conditions (= continuous air flow $-50 \mathrm{ml} \mathrm{min}^{-1}$ - through the vial during fiber exposure). SPME samples were analyzed immediately.

\subsection{GC x GC-TOFMS measurements}

All ATD and SPME samples were analyzed using a Leco Pegasus 4D GC $\times$ GC-TOFMS (Leco, St. Joseph, Michigan). Unlike the efforts using ATD, with SPME no calibration standard runs were made: the primary purpose of the SPME runs was to provide samples that could easily indicate the level of sample complexity that is to be encountered in analyses of VBOCs, and easily provide needed retention time data. For all ATD cartridges (standard or sample or blank, NCAR or PSU), prior to analysis each cartridge was loaded with the IS compounds by injecting $0.2 \mathrm{ml}$ of the IS gas standard into a $50 \mathrm{ml} \mathrm{min}^{-1}, 5 \mathrm{~min}$ flow of precleaned $\mathrm{N}_{2}$ leading to the sample inlet end of the cartridge. For a standard cartridge, the 21 target analyte compounds were then added by injecting $4 \mu \mathrm{l}$ of one of the methanolic standard mix solutions into the inlet of the cartridge; most of the methanol was then removed and the analytes were moved further onto the cartridge by a $50 \mathrm{ml} \mathrm{min}^{-1}, 5 \mathrm{~min}$ flow of precleaned $\mathrm{N}_{2}$.

The ATD 400 (Perkin-Elmer, Waltham, MA) thermal desorption apparatus was connected to the GC injector by a fused silica transfer line $\left(220^{\circ} \mathrm{C}\right)$. Each ATD cartridge was thermally desorbed $\left(270^{\circ} \mathrm{C}, 10 \mathrm{~min}\right)$ at $40 \mathrm{ml} \mathrm{min}^{-1}$ with zero split to a focusing trap $\left(45 \mathrm{mg}\right.$ of $\left.\mathrm{Tenax}^{\mathrm{TM}} \mathrm{TA}, 10^{\circ} \mathrm{C}\right)$ in the ATD 400 . The focusing trap was desorbed $\left(290^{\circ} \mathrm{C}\right.$, $3 \mathrm{~min}$ ) with zero split (splitless) to the fused silica transfer line and thus the GC injector. Flow from the GC injector to the primary GC column occurred with a $15: 1$ split. (Increased method sensitivity could have been achieved by reducing the split to as low as 5:1 without reduction of 
Table 3. Summary of GC $\times$ GC-TOFMS conditions used in VBOC determinations.

\begin{tabular}{|c|c|c|}
\hline & initial & improved \\
\hline GC injector & $250^{\circ} \mathrm{C} ;$ split $20: 1$ for ATD & $225^{\circ} \mathrm{C}$; split $15: 1$ for ATD, splitless for SPME \\
\hline column flow & $1.2 \mathrm{ml} \mathrm{min}^{-1}$ (mass flow controller) & $1.0 \mathrm{ml} \mathrm{min}-1$ (mass flow controller) \\
\hline primary column & $\begin{array}{l}\text { non-polar: Rxi-5ms, } 30 \mathrm{~m}, 0.25 \mathrm{~mm} \text { I.D., } \\
0.25 \mu \mathrm{m} \text { film (Restek, Bellefonte, PA) }\end{array}$ & $\begin{array}{l}\text { low polarity: DB-VRX, } 45 \mathrm{~m}, 0.25 \mathrm{~mm} \text { I.D., } \\
1.4 \mu \mathrm{m} \text { film (Agilent, Santa Clara, CA) }\end{array}$ \\
\hline GC $\times$ GC modulation & $4 \mathrm{~s}$ period, $0.8 \mathrm{~s}$ hot pulse & $4 \mathrm{~s}$ period, $0.9 \mathrm{~s}$ hot pulse \\
\hline $\mathrm{GC} \times \mathrm{GC}$ modulator & \multicolumn{2}{|c|}{ trap with cold gas from LN2, then hot pulse at $20^{\circ}$ above primary oven for release to secondary column } \\
\hline secondary column & $\begin{array}{l}\text { polar: BPX-50, } 1.25 \mathrm{~m}, 0.10 \mathrm{~mm} \text { I.D., } \\
0.10 \mu \mathrm{m} \text { film (SGE, Austin, TX) }\end{array}$ & $\begin{array}{l}\text { polar: Stabilwax }{ }^{\mathrm{TM}}, 1.5 \mathrm{~m}, 0.25 \mathrm{~mm} \text { I.D., } \\
0.25 \mu \mathrm{m} \text { film (Restek, Bellefonte, PA). }\end{array}$ \\
\hline $\begin{array}{l}\text { GC program } \\
\text { (primary oven) }\end{array}$ & $\begin{array}{l}40^{\circ} \mathrm{C} \text { for } 5 \mathrm{~min}, 15^{\circ} \mathrm{C} \min ^{-1} \text { to } 300^{\circ} \mathrm{C} \text {, then } \\
\text { hold at } 300^{\circ} \mathrm{C} \text { for } 5 \mathrm{~min}\end{array}$ & $\begin{array}{l}45^{\circ} \mathrm{C} \text { for } 5 \mathrm{~min}, 10^{\circ} \mathrm{C} \mathrm{min}^{-1} \text { to } 175^{\circ} \mathrm{C} \text {, hold } \\
\text { at } 175^{\circ} \mathrm{C} \text { for } 2 \mathrm{~min}, 4^{\circ} \mathrm{Cmin}^{-1} \text { to } 240^{\circ} \mathrm{C} \text {, } \\
\text { then hold at } 240^{\circ} \mathrm{C} \text { for } 10 \mathrm{~min}\end{array}$ \\
\hline MS source & \multicolumn{2}{|c|}{$200^{\circ} \mathrm{C}$, electron impact $(70 \mathrm{eV})$} \\
\hline MS detector & \multicolumn{2}{|r|}{$1550 \mathrm{~V}$} \\
\hline MS data acquisition & \multicolumn{2}{|c|}{150 spectra $^{-1} ; 35$ to $500 \mathrm{amu}$} \\
\hline
\end{tabular}

chromatographic performance.) SPME fibers were desorbed splitless for $3 \mathrm{~min}$ in the $\mathrm{GC}$ injector $\left(225^{\circ} \mathrm{C}\right)$ which contained an SPME liner (Restek, Bellefonte, PA). Thereafter, an injector purge flow of $100 \mathrm{ml} \mathrm{min}^{-1}$ was kept open for 4 min. Each $\mathrm{GC} \times \mathrm{GC}$ run was initiated immediately upon beginning of the heating of the focusing trap (ATD), or after the SPME fiber was inserted into the injector (SPME). In every case, TOFMS data collection was delayed 180s. An initial set and an improved set of GC columns/conditions were used (Table 3).

\section{Results and discussion}

\subsection{Detection limits}

The particular MDL values for the 21 target compounds investigated here are provided in Table 4. For isoprene, the MDL was $3.5 \mathrm{pptv}\left(10 \mathrm{ng} \mathrm{m}^{-3}\right)$. For the monoterpenes, the MDL values were in the range $0.7-2.1 \mathrm{pptv}$ ( 4 to $\left.12 \mathrm{ng} \mathrm{m}^{-3}\right)$. For the sesquiterpenes, the MDL values were $\sim 1$ pptv $\left(\sim 10 \mathrm{ng} \mathrm{m}^{-3}\right)$. No blank problems were experienced for any of the target compounds. As such, all MDL values were assessed by varying the on-cartridge mass amounts of the target analytes, and determining which values yielded an instrument signal to noise ratio of 10:1. MDL values were then calculated as equaling the mass amounts at 10:1 signal-to-noise divided by the sample volume of 51 .

\subsection{Chromatograms}

Figures 2-6 show chromatograms for samples run using the improved set of chromatographic conditions (Table 3) unless stated otherwise. Figure $2 \mathrm{a}$ and $\mathrm{b}$ are $\mathrm{GC} \times \mathrm{GC}$-TOFMS chromatograms obtained by ATD for the 21-compound standard mix. Good separation was achieved for all of the compounds except for $\alpha$-cedrene and caryophyllene. The latter two compounds possess sufficiently different EI mass spectra that they are differentiable even when not fully resolved chromatographically.

In sample runs, the peak selection criteria (PSC) used to decide upon which chromatographic peaks would receive further consideration were applied on the Leco data system as follows: signal to noise ratio $>200$, peak area $>100000$, and match similarity of $>780$ with an entry in the NIST mass spectral library. For each sample, some of those peaks corresponded to target compounds, and eluted at the proper retention times, and so were positively identified. Other peaks passing the PSC but not corresponding to the target compounds were considered only tentatively identified. Table S1 (Supplement) summarizes the information acquired for 438 chromatographic peaks (including 21 standard compounds) that met the PSC in the various chromatograms presented here.

\section{- Calycolpus, ATD, ambient air:}

Figure 3 is a chromatogram for an ATD sample obtained during an NCAR enclosure experiment using the lower branch of a tree (Calycolpus moritzianus) growing in a tropical forest in South America (Columbia, $11.0704^{\circ} \mathrm{N}, 74.0411^{\circ} \mathrm{W}$ ). For this sample, the initial set of chromatographic conditions was used (Table 3 ). The peaks for 15 of the 21 standard compounds met the PSC and were positively identified based on their chromatographic retention times and mass spectra (Table S2, Supplement); four of these ( $\alpha$-pinene, limonene, 

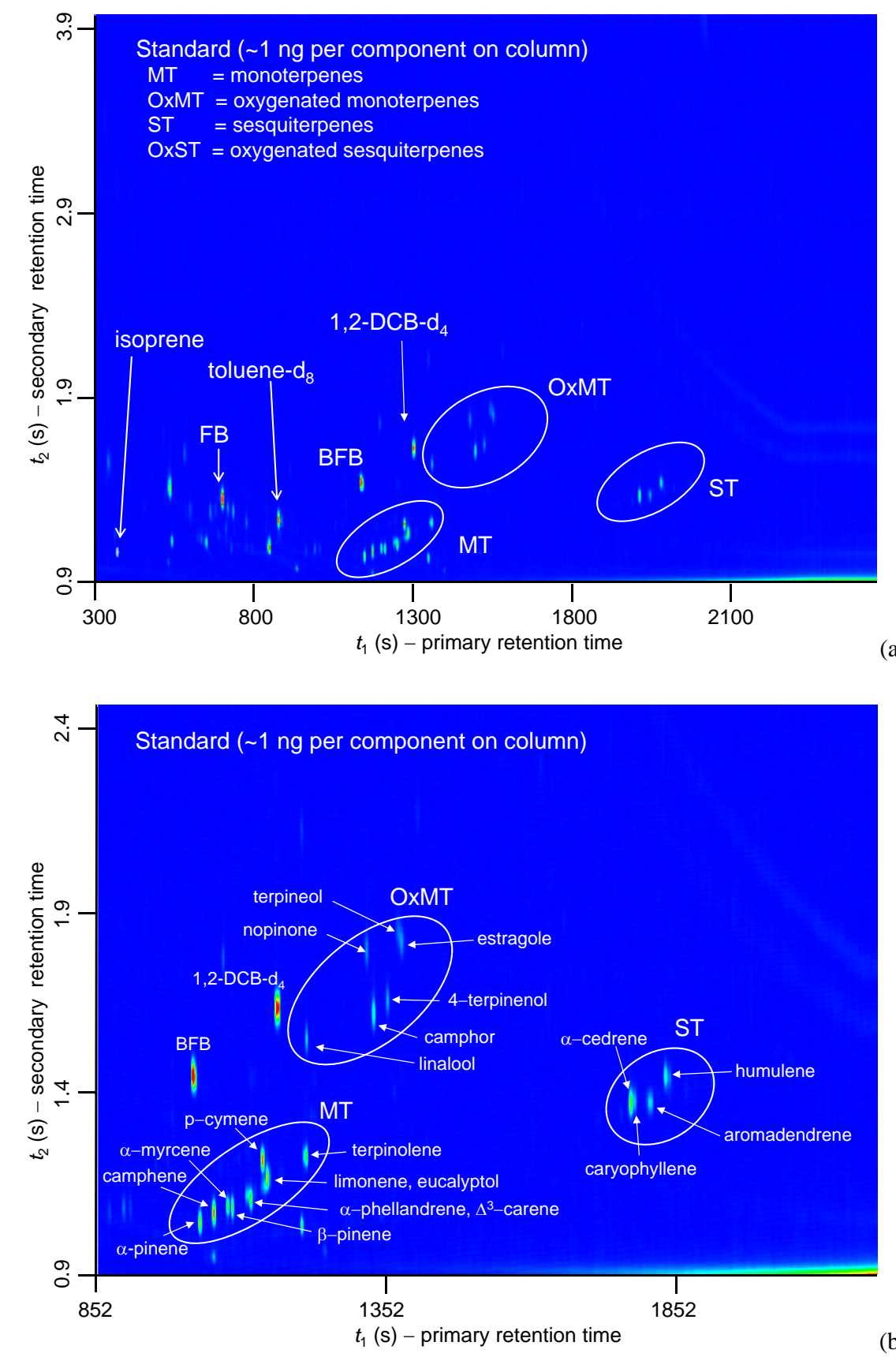

(a)

(b)

Fig. 2. (a) GC $\times$ GC-TOFMS chromatogram of a standard containing 21 VBOCs at $\sim 1$ ng per component on-column; internal standard compounds are fluorobenzene (FB), toluene-d8, bromofluorobenzene (BFB), and 1,2-DCB-d4 (1,2-dichlorobenzene-d4); obtained using the improved chromatographic conditions (Table 3). (b) Enlarged region of GC $\times$ GC-TOFMS chromatogram showing 20 VBOCs at $\sim 1$ ng per component on-column.

$\alpha$-terpineol, and caryophyllene) are known constituents of $C$. moritzianus essential oils (Valdés et al., 2006; Diaz et al., 2008). Peaks for another two standard compounds were positively identified based on their mass spectral and retention time data, though were too small to meet the PSC. The number of tentatively identified peaks meeting the PSC in Fig. 3 totaled 127 (Table S2,
Supplement) and included four monoterpenes and 10 sesquiterpenes. In addition, at levels two to five times larger than blank levels, three of the 127 peaks were identified as salicylates (methyl salicylate, 2-ethylhexyl salicylate, and homomenthyl salicylate). Two of the 127 peaks matched well as isomers of cumene and two matched well as isomers of aromadendrene. Overall, at 


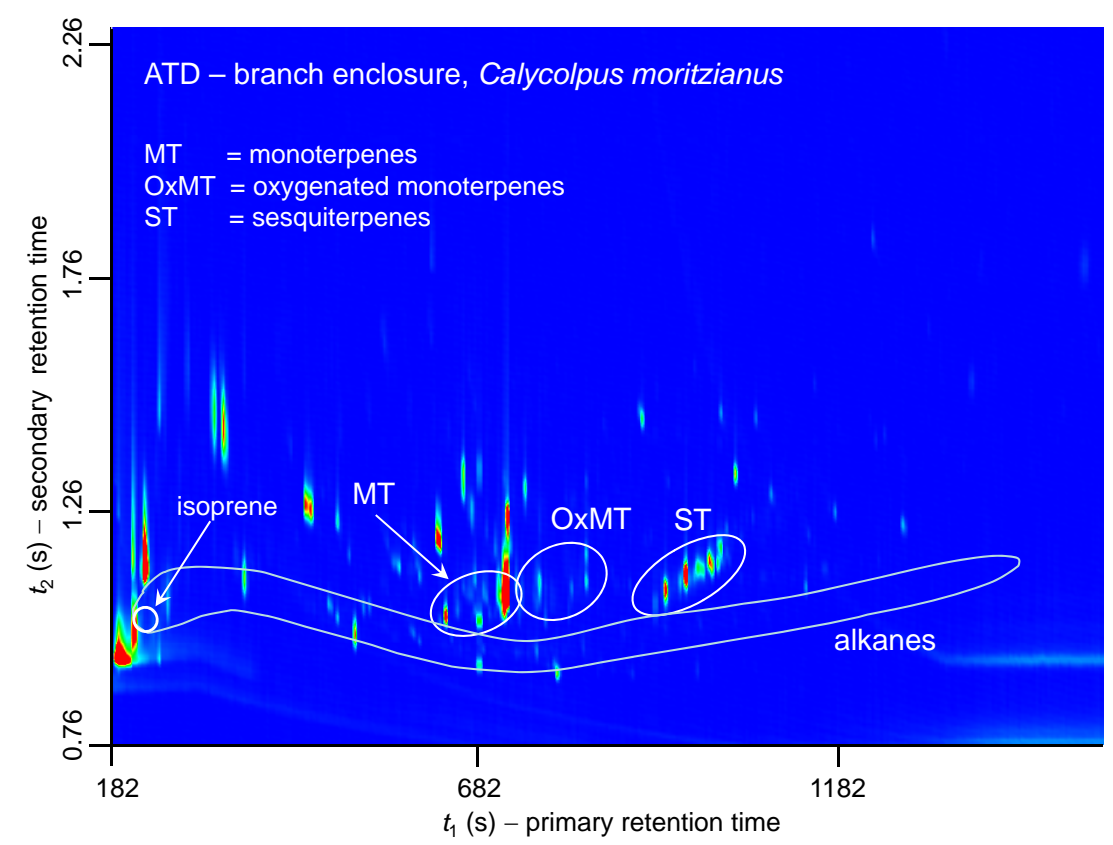

Fig. 3. GC $\times$ GC-TOFMS chromatogram of VBOCs from Calycolpus moritzianus by ATD using a branch enclosure in the field; obtained using the "initial" chromatographic conditions (Table 3).

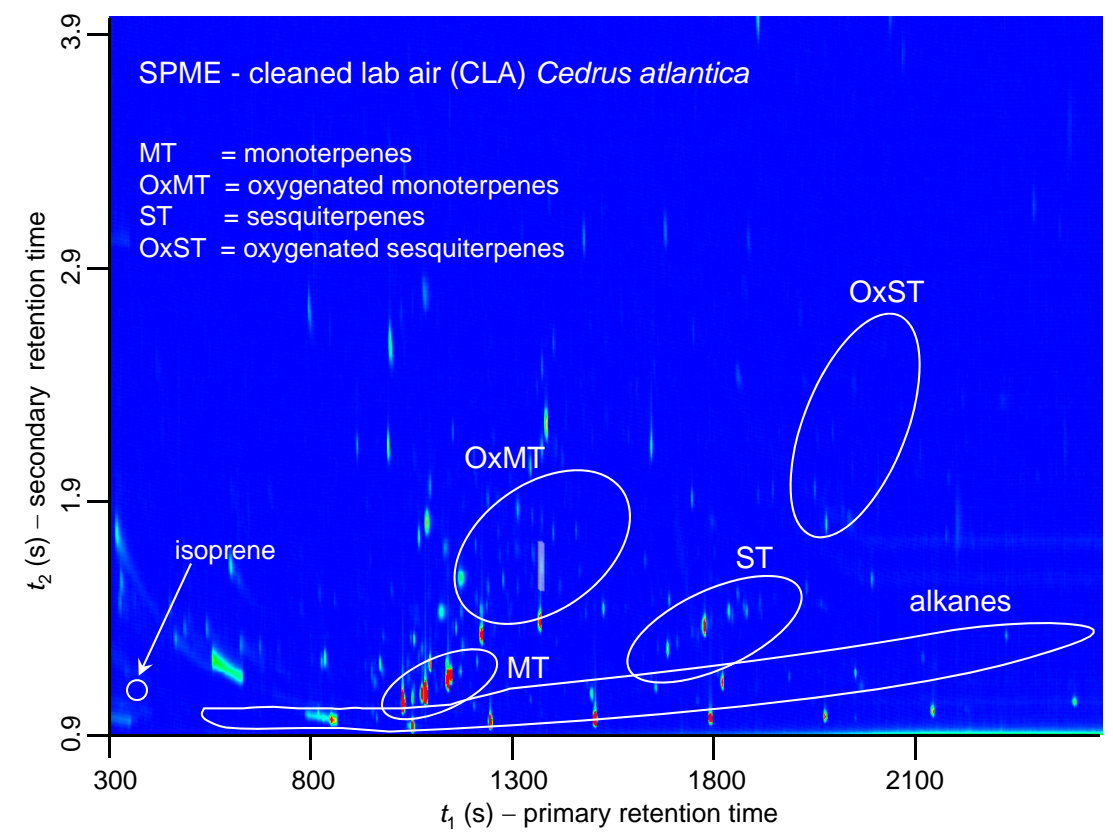

Fig. 4. GC $\times$ GC-TOFMS chromatogram of VBOCs from Cedrus atlantica by SPME and using cleaned laboratory air (CLA); obtained using the "improved" chromatographic conditions (Table 3).

least 13 sesquiterpene compounds were present at easily detectable concentrations. For these and the tentative identifications discussed below for Figs. 4-6, confirmed identifications will await acquisition of suitable authentic standards.
- Cedrus, SPME, laboratory air (cleaned):

Figure 4 is a chromatogram for VBOCs emitted from Cedrus atlantica needles sampled in Portland (December 2010). Sampling took place with SPME using the cleaned laboratory air (CLA) using dynamic sampling conditions as described above. The peaks for 10 of the 


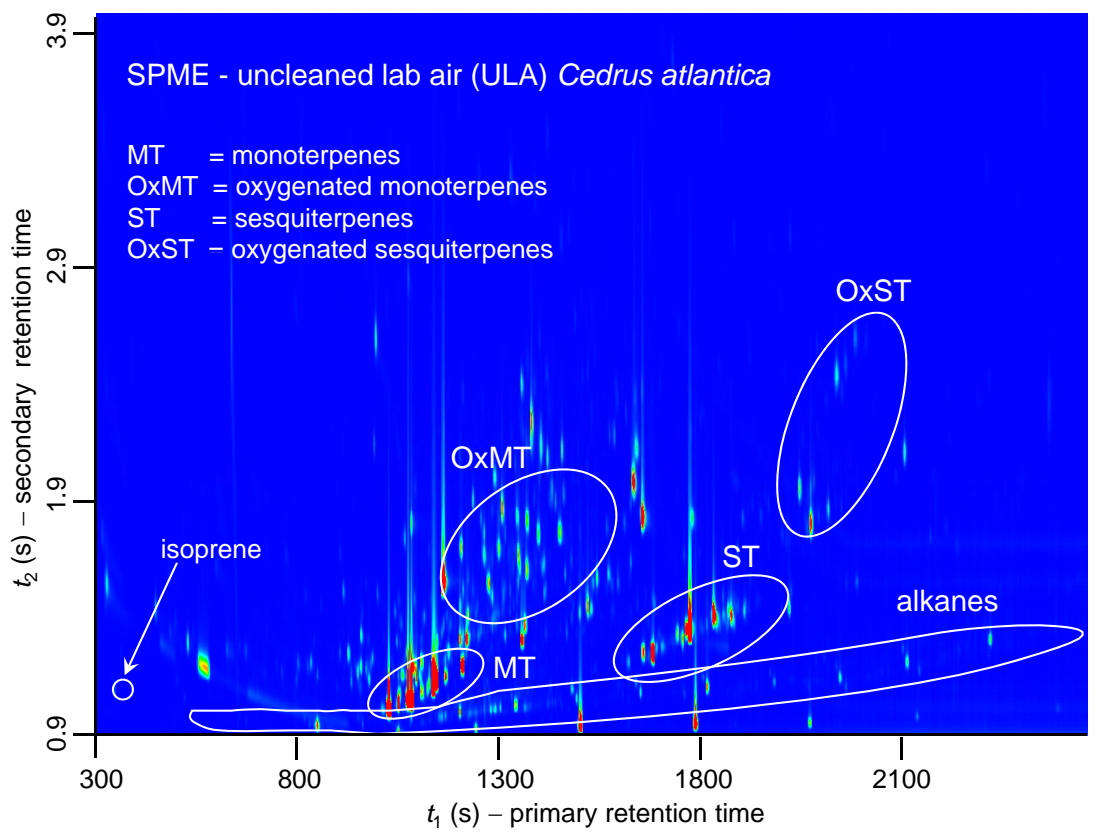

Fig. 5. GC $\times$ GC-TOFMS chromatogram of VBOCs from Cedrus atlantica by SPME using uncleaned laboratory air (ULA); obtained using the "improved" chromatographic conditions (Table 3).

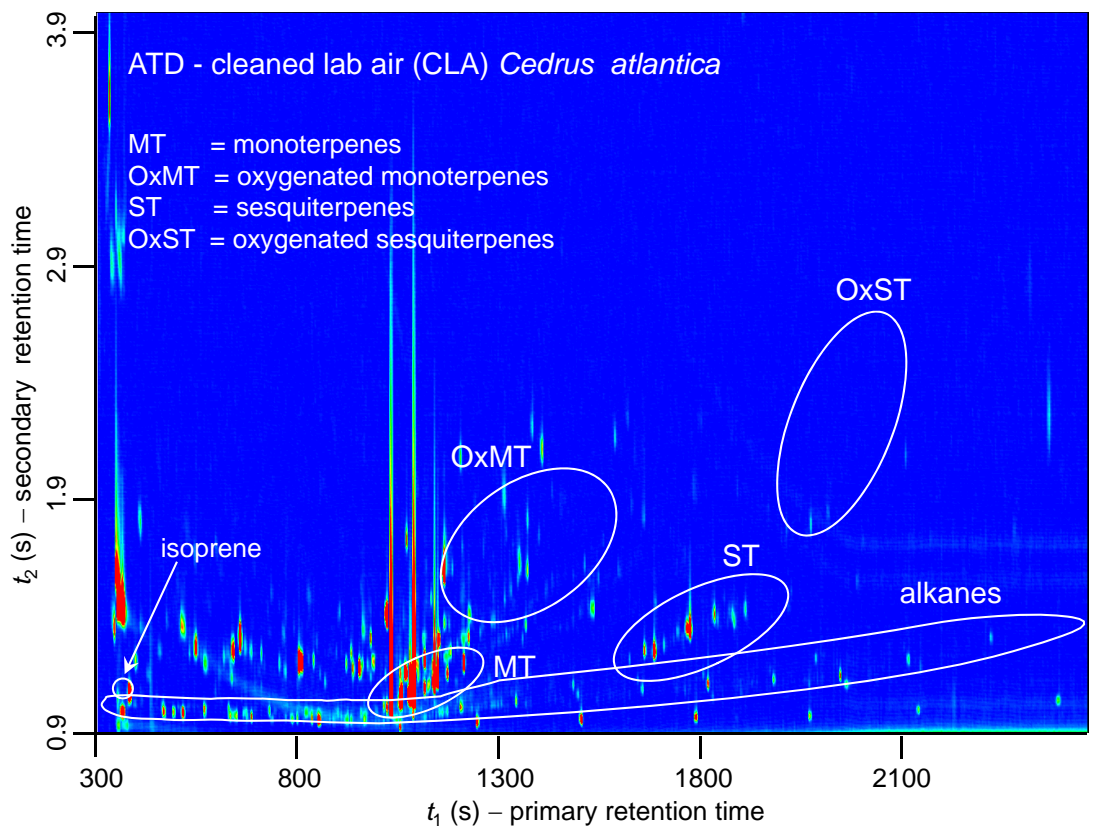

Fig. 6. GC $\times$ GC-TOFMS chromatogram of VBOCs from Cedrus atlantica by ATD using cleaned laboratory air (CLA); obtained using the "improved" chromatographic conditions (Table 3).

21 standard compounds met the PSC and were positively identified based on their chromatographic retention times and mass spectra (Table S3, Supplement); peaks for another five standard compounds were positively identified based on their mass spectral and retention time data, though were too small to meet the
PSC. The number of tentatively identified peaks meeting the PSC totaled 92; these included tentative identifications for methacrolein, methyl vinyl ketone, hexenal, two monoterpenes, four oxygenated monoterpenes, four sesquiterpenes, and one oxygenated sesquiterpene (Table S3, Supplement). 
Table 4. Minimum detection limit values (MDL) at 10:1 signal to noise for determination by adsorption/thermal desorption (ATD) with a sample volume of 51 followed by GC $\times$ GC-TOFMS.

\begin{tabular}{|c|c|c|c|c|}
\hline \multirow[t]{2}{*}{ Compound } & \multirow{2}{*}{$\begin{array}{l}\text { Molecular } \\
\text { formula }\end{array}$} & \multirow{2}{*}{$\begin{array}{c}\text { CAS } \\
\text { number }\end{array}$} & \multicolumn{2}{|c|}{$\mathrm{MDL}^{\mathrm{b}}$} \\
\hline & & & $\operatorname{ng~m} m^{-3}$ & $\operatorname{pptv}^{\mathrm{c}}$ \\
\hline \multicolumn{5}{|c|}{ hemiterpenes } \\
\hline isoprene & $\mathrm{C}_{5} \mathrm{H}_{8}$ & $78-79-5$ & 10 & 3.5 \\
\hline \multicolumn{5}{|c|}{ monoterpenes and related compounds } \\
\hline$\alpha$-pinene & $\mathrm{C}_{10} \mathrm{H}_{16}$ & $80-56-8$ & 8 & 1.4 \\
\hline camphene & $\mathrm{C}_{10} \mathrm{H}_{16}$ & $79-92-5$ & 8 & 1.4 \\
\hline$\alpha$-myrcene & $\mathrm{C}_{10} \mathrm{H}_{16}$ & $123-35-3$ & 8 & 1.4 \\
\hline$\beta$-pinene & $\mathrm{C}_{10} \mathrm{H}_{16}$ & $127-91-3$ & 8 & 1.4 \\
\hline$\alpha$-phellandrene & $\mathrm{C}_{10} \mathrm{H}_{16}$ & $99-83-2$ & 12 & 2.1 \\
\hline$\Delta^{3}$-carene & $\mathrm{C}_{10} \mathrm{H}_{16}$ & $13466-78-9$ & 8 & 1.4 \\
\hline limonene & $\mathrm{C}_{10} \mathrm{H}_{16}$ & $138-86-3$ & 12 & 2.1 \\
\hline$p$-cymene & $\mathrm{C}_{10} \mathrm{H}_{14}$ & $527-84-4$ & 4 & 0.7 \\
\hline eucalyptol & $\mathrm{C}_{10} \mathrm{H}_{18} \mathrm{O}$ & $470-82-6$ & 8 & 1.2 \\
\hline terpinolene & $\mathrm{C}_{10} \mathrm{H}_{16}$ & $586-62-9$ & 6 & 1.1 \\
\hline linalool & $\mathrm{C}_{10} \mathrm{H}_{18} \mathrm{O}$ & $78-70-6$ & 12 & 1.9 \\
\hline nopinone & $\mathrm{C}_{9} \mathrm{H}_{14} \mathrm{O}$ & $38651-65-9$ & 12 & 2.1 \\
\hline camphor & $\mathrm{C}_{10} \mathrm{H}_{16} \mathrm{O}$ & $76-22-2$ & 8 & 1.3 \\
\hline 4-terpinenol & $\mathrm{C}_{10} \mathrm{H}_{18} \mathrm{O}$ & $562-74-3$ & 10 & 1.6 \\
\hline terpineol & $\mathrm{C}_{10} \mathrm{H}_{18} \mathrm{O}$ & $98-55-5$ & 12 & 1.9 \\
\hline estragole & $\mathrm{C}_{10} \mathrm{H}_{12} \mathrm{O}$ & $140-67-0$ & 10 & 1.6 \\
\hline \multicolumn{5}{|c|}{ sesquiterpenes } \\
\hline$\alpha$-cedrene & $\mathrm{C}_{15} \mathrm{H}_{24}$ & $469-61-4$ & 12 & 1.4 \\
\hline caryophyllene & $\mathrm{C}_{15} \mathrm{H}_{24}$ & $87-44-5$ & 12 & 1.4 \\
\hline aromadendrene & $\mathrm{C}_{15} \mathrm{H}_{24}$ & $489-39-4$ & 8 & 0.9 \\
\hline humulene & $\mathrm{C}_{15} \mathrm{H}_{24}$ & $6753-98-6$ & 8 & 0.9 \\
\hline
\end{tabular}

a CAS numbers are for the forms of the compounds as purchased (Sigma-Aldrich, St. Louis, MO) for use as standard materials.

b No blank contamination problems were encountered for any of the compounds; zero split during desorption from sample cartridge to secondary focusing trap within ATD unit; 1 in 15 split between secondary focusing cartridge and the primary column; total fraction of sample mass transferred to column $=6.7 \%$. Other GCxGC and TOFMS conditions as given in text.

${ }^{\mathrm{c}}$ pptv $=$ parts per trillion by volume. Conversion between $\mathrm{ng} \mathrm{m}^{-3}$ and pptv by the ideal gas law and assuming temperature $T=293 \mathrm{~K}$ and total pressure $P=1 \mathrm{~atm}$.

- Cedrus, SPME, laboratory air (uncleaned):

Figure 5 is a chromatogram for VBOCs emitted from Cedrus atlantica needles sampled in Portland (October 2010). Sampling took place with SPME using ULA and dynamic sampling conditions. The considerably greater complexity in Fig. 5 compared to Fig. 4 is the consequence of: (a) the many VOCs present in the ambient laboratory air (i.e., in the ULA); (b) the greater oxidation potential (i.e., higher ozone level) in the ULA; and (c) the presumed higher level of biological activity for the Fig. 5 sample (collected in October) as compared to that for the Fig. 4 sample (collected in December).
The peaks for 18 of the 21 standard compounds met the PSC and were positively identified based on their chromatographic retention times and mass spectra (Table S4, Supplement); the peak for one additional standard compound was positively identified based on its mass spectral and retention time data, though was too small to meet the PSC. The 18 compounds included all 10 of the PSC-satisfying standard compounds found in the Fig. 4 chromatogram. In Fig. 5, the number of tentatively identified peaks meeting the PSC totaled 312 (Table S4, Supplement). Compared to the Fig. 4 chromatogram, the Fig. 5 chromatogram evidenced the presence of the following numbers of additional compounds: six monoterpenes; 30 oxygenated monoterpenes; 26 sesquiterpenes; 10 oxygenated sesquiterpenes. As compelling evidence of the complexity of the VBOC group, among the 312 tentative identifications, there are nine examples of multiple peaks matching well as the same compound: (1) four peaks as E,E-2,6-dimethyl-1,3,5,7-octatetraene; (2) two peaks as 3-methyl-undecane; (3) two peaks as $\gamma$-terpinene; (4) three peaks as d-verbenol; (5) two peaks as trans1-methyl-4-(1-methylethly)-2-cyclohexen-1-ol; (6) two peaks as $\beta$-cubebene; (7) two peaks as germacrene $\mathrm{D}$; (8) two peaks as longipinocarvone; and (9) four peaks as caryophyllene oxide.

\section{- Cedrus, ATD, laboratory air (cleaned):}

Figure 6 is a chromatogram for the VBOCs emitted from needles of Cedrus atlantica obtained using ATD and the CLA. Compared to Fig. 4 (SPME with CLA), Fig. 6 is considerably more complex for low primary retention times $\left(t_{1}<950 \mathrm{~s}\right)$. This is due to the greater ability of ATD to collect highly volatile compounds: the gas-to-fiber partition coefficients for SPME for such compounds are low. The peaks for 15 of the 21 standard compounds met the PSC and were positively identified based on their chromatographic retention times and mass spectra (Table S5, Supplement); peaks for another three standard compounds were positively identified based on their mass spectral and retention time data, though were too small to meet the PSC. In Fig. 6, the number of tentatively identified peaks meeting the PSC totaled 127 (Table S5, Supplement).

\subsection{Chromatographic retention information}

\subsubsection{First dimension retention index}

For the primary column, the $t_{1}$ retention time data were transformed into Kovats retention index values $I_{1}$ so as to obtain generally useful measures of retention that are much more system-independent than simple $t_{1}$ values. On the primary column, for compound $i$ eluting at retention time $t_{1, i}$ and between straight-chain alkanes with carbon numbers $j$ and 
$j+1$, the non-isothermal retention index values were calculated as (Guiochon, 1964)

$$
I_{1, i}=100\left[j+\frac{t_{1, i}-t_{1, j}}{t_{1, j+1}-t_{1, j}}\right]=100 n_{\mathrm{C}, i} .
$$

The $t_{1, j}$ and $t_{1, j+1}$ values were available because of the natural presence in the samples of 15 straight-chain alkanes $\left(\mathrm{C}_{5}\right.$ to $\left.\mathrm{C}_{19}\right) . n_{\mathrm{C}, i}$ is the carbon number for the hypothetical equivalent straight-chain alkane that elutes in the first dimension at $t_{1, i}$. For most $i, n_{\mathrm{C}, i}$ will not be an integer. Table $\mathrm{S} 1$ (in the Supplement) provides $I_{1}$ values for the 21 target analyte BVOCs in the standard mix utilized here and for 417 tentatively identified compounds found in the four different sample chromatograms discussed above. Of the 417 tentative identifications in Table S1 (Supplement), six resulted from search similarity values in the range 680-699, while 56 resulted from values in the range 700-799, and 355 resulted from values in the range 800-990.

\subsubsection{Second dimension retention ratio}

Because of the shortness of the secondary column, the maximum retention time in the second dimension is only a few seconds and thus too short to allow elution of bracketing compounds before and after every compound appearing in any given secondary chromatogram. Thus, a retention index analogous to that defined by Eq.(1) is difficult to achieve for the second dimension, and a simple retention time ratio $R_{2, i}$ is more practical. The secondary retention time $t_{2}$ of the hypothetical straight-chain alkane with carbon number $n_{\mathrm{C}, i}$ is a logical choice for use as the normalizing $t_{2}$ value according to

$$
R_{2, i}=\frac{t_{2, i}}{t_{2, n_{\mathrm{C}, i}}}
$$

The needed values of $t_{2, n_{\mathrm{C}, i}}$ were obtained as follows. The value of the secondary retention time $t_{2}$ was determined for each actual straight-chain alkane with integer value of $n_{\mathrm{C}}$. Data pairs $\left(t_{2, n_{\mathrm{C}}}, n_{\mathrm{C}}\right)$ were thus available from the 15 straight-chain alkanes $\left(\mathrm{C}_{5}\right.$ to $\left.\mathrm{C}_{19}\right)$ naturally present in the samples. Those data were fit to obtain $t_{2, n_{\mathrm{C}}}$ expressed as a 6th order polynomial in $n_{\mathrm{C}}$. The polynomial was used to calculate the needed $t_{2, n_{\mathrm{C}, i}}$ values. Table S1 (in the Supplement) provides $R_{2}$ values for the 21 target analyte VBOCs in the standard mix utilized here and for the 417 tentatively identified compounds found in the four different sample chromatograms. The $I_{1}$ and $R_{2}$ values in Table $\mathrm{S} 1$ (in the Supplement) will be generally useful in subsequent studies that seek to identify and quantify individual compounds in complex VBOCs samples.

\section{Conclusions}

The results from this and other studies illustrate the enormous complexity of the VBOC group. Any serious effort to comprehensively examine this complexity will need to involve $\mathrm{GC} \times \mathrm{GC}$. As shown here even a small number of different types of samples can be expected to reveal the presence of many hundreds (if not thousands) of compounds of interest for atmospheric chemistry. For example, even though the annual global mass emissions of individual sesquiterpenes may be very low, the aggregate emission of all sesquiterpenes may well be a significant source for the carbon present in global atmospheric organic particulate matter. For VBOC sample collection, while SPME is a valuable method, for quantitative measurements ATD is significantly more robust and more easily applied.

Although the analytical methodologies required for comprehensive characterization of VBOCs in all sample types of interest are in place (i.e., either ATD or SPME interfaced with $\mathrm{GC} \times \mathrm{GC}$-TOFMS), progress in this field will be much accelerated when substantially more VBOCs can be obtained as authentic, high purity standard materials. In the meantime, advances can be made by resorting to impure mixtures, as with essential oils known to contain particular VBOCs of interest. Much additional GC $\times$ GC retention time data for authentic standard compounds of the type collected here are needed.

\section{Supplementary material related to this article is available online at: http://www.atmos-meas-tech.net/5/345/2012/ amt-5-345-2012-supplement.pdf.}

Acknowledgements. The authors are grateful for financial and other support from the Cooley Family Fund for Critical Research of the Oregon Community Foundation, for support obtained through the Institute for Sustainable Solutions at Portland State University, and for the support of Patrick Coughlin, Regina and Mike Dowd, Keith Park, and Steven T. Huff. The authors also express their appreciation to Jack W. Cochran of Restek Inc. for helpful discussions regarding the optimization of the chromatographic conditions.

Edited by: D. Heard

\section{References}

Arey, J. S., Nelson, R. K., Xu, L., and Reddy, C. M.: Using comprehensive two-dimensional gas chromatography retention indices to estimate environmental partitioning properties for a complete set of diesel fuel hydrocarbons, Anal. Chem., 77, 7172-7182, 2005.

Arnts, R. R.: Evaluation of adsorbent sampling tube materials and Tenax-TA for analysis of volatile biogenic organic compounds, Atmos. Environ., 44, 1579-1584, 2010. 
Baker, B. and Sinnott, M. J.: Analysis of sesquiterpene emissions by plants using solid phase microextraction, J. Chromatogr. A, 1216, 8442-8451, 2009.

Bamberger, I., Hörtnagl, L., Schnitzhofer, R., Graus, M., Ruuskanen, T. M., Müller, M., Dunkl, J., Wohlfahrt, G., and Hansel, A.: BVOC fluxes above mountain grassland, Biogeosciences, 7 , 1413-1424, doi:10.5194/bg-7-1413-2010, 2010.

Batterman, S. A., Zhang, G.-Z., and Baumann, M.: Analysis and stability of aldehydes and terpenes in electropolished canisters, Atmos. Environ., 32, 1647-1655, 1998.

Bidleman, T.: Atmospheric processes, Environ. Sci. Technol., 22, 361-387, 1988.

Bouvier-Brown, N. C., Holzinger, R., Palitzsch, K., and Goldstein, A. H.: Quantifying sesquiterpene and oxygenated terpene emissions from live vegetation using solid-phase microextraction fibers, J. Chromatogr. A, 1161, 113-120, 2007.

Bouvier-Brown, N. C., Goldstein, A. H., Gilman, J. B., Kuster, W. C., and de Gouw, J. A.: In-situ ambient quantification of monoterpenes, sesquiterpenes, and related oxygenated compounds during BEARPEX 2007: implications for gas- and particle-phase chemistry, Atmos. Chem. Phys., 9, 5505-5518, doi:10.5194/acp-9-5505-2009, 2009a.

Bouvier-Brown, N. C., Holzinger, R., Palitzsch, K., and Goldstein, A. H.: Large emissions of sesquiterpenes and methyl chavicol quantified from branch enclosure measurements, Atmos. Environ., 43, 389-401, 2009b.

Calogirou, A., Larson, B. R., Brussol, C., Duane, M., and Kotzias, D.: Decomposition of terpenes by ozone during sampling on Tenax, Anal. Chem., 68, 1499-1506, 1996.

Cao, X. and Hewitt, C. N.: Thermal desorption efficiencies for different adsorbate/adsorbent systems typically used in air monitoring programmes, Chemosphere, 27, 695-705, 1993.

Cao, X. and Hewitt, C. N.: Study of the degradation by ozone of adsorbents and of hydrocarbons adsorbed ruing the passive sampling of air, Environ. Sci. Technol., 28, 757-762, 1994.

Chen, J., Avise, J., Lamb, B., Salathé, E., Mass, C., Guenther, A., Wiedinmyer, C., Lamarque, J.-F., O’Neill, S., McKenzie, D., and Larkin, N.: The effects of global changes upon regional ozone pollution in the United States, Atmos. Chem. Phys., 9, 11251141, doi:10.5194/acp-9-1125-2009, 2009.

Cochran, J. J.: Evaluation of comprehensive two-dimensional gas chromatography - time-of-flight mass spectrometry for the determination of pesticides in tobacco, J. Chromatogr. A, 1186, 202-210, 2008.

de Gouw, J. A., Middlebrook, A. M., Warneke, C., Ahmadov, R., Atlas, E. L., Bahreini, R., Blake, D. R., Brock, C. A., Brioude, J., Fahey, D. W., Fehsenfeld, F. C., Holloway, J. S., Le Henaff, M., Lueb, R. A., McKeen, S. A., Meagher, J. F., Murphy, D. M., Paris, C., Parrish, D. D., Perring, A. E., Pollack, I. B., Ravishankara, A. R., Robinson, A. L., Ryerson, T. B., Schwarz, J. P., Spackman, J. R., Srinivasan, A., and Watts, L. A.: Organic aerosol formation downwind from the Deepwater Horizon oil spill, Science, 331, 1295-1299, 2011.

Dettmer, K. and Engewald, W.: Adsorbent materials commonly used in air analysis for adsorptive enrichment and thermal desorption of volatile organic compounds, Anal. Bioanal. Chem., 373, 490-500, 2002.
Diaz, T., Mora, F. D., Velasco, J., Diaz, T., Rojas, L. B., Usubillaga, A., and Juan, C. A.: Chemical composition and in vitro antibacterial activity of the essential oil off Calycolpus moritzianus (O. Berg) Burret from Merida, Venezuela, Nat. Prod. Commun., 3, 937-940, 2008.

Di Carlo, P., Brune, W. H., Martinez, M., Hartwig, H., Lesher, R., Ren, X., Thornberry, T., Carroll, M. A., Young, V., Shepson, P. B., Riemer, D., Apel, E., and Campbell, C.: Missing OH reactivity in a forest: Evidence for unknown reactive biogenic VOCs, Science, 30, 722-725, 2004.

Fastyn, P., Kornacki, W., Gierczak, T., Gawłowski, J., and Niedzielski, J.: Adsorption of water vapour from humid air by selected carbon adsorbents, J. Chromatog. A, 1078, 7-12, 2005.

Fick, J., Pommer, L., Andersson, B., and Nilsson, C: Ozone removal in the sampling of parts per billion levels of terpenoid compounds: An evaluation of different scrubber materials, Environ. Sci. Technol., 35, 1458-1462, 2001.

Frysinger, G. S., Gaines, R. B., Xu, L., and Reddy, C. M.: Resolving the unresolved complex mixture in petroleum-contaminated sediments, Environ. Sci. Technol., 37, 1653-1662, 2003.

Geron, C. D. and Arnts, R. R.: Seasonal monoterpene and sesquiterpene emissions from Pinus taeda and Pinus virginiana, Atmos. Environ., 44, 4240-4251, 2010.

Goldstein, A. H. and Galbally, I. E.: Known and unexplored organic constituents in the Earth's atmosphere, Environ. Sci. Technol., 41, 1514-1521, 2007.

Goldstein, A. H., McKay, M., Kurpius, M. R., Schade, G. W., Lee, A., Holzinger, R., and Rasmussen, R. A.: Forest thinning experiment confirms ozone deposition to forest canopy is dominated by reaction with biogenic VOCs, Geophys. Res. Lett., 31, L22106, doi:10.1029/2004GL021259, 2004.

Goldstein, A. H., Koven, C. D., Heald, C. L., and Fung, I. Y.: Biogenic carbon and anthropogenic pollutants combine to form a cooling haze over the southeastern US, P. Natl. Acad. Sci., 106, 8835-8840, 2009.

Grabmer, W., Kreuzwieser, J., Wisthale, A., Cojocariu, C., Graus, M., Rennenberg, H., Steigner, D., Steinbrecher, R., and Hansel, A.: VOC emissions from Norway spruce (Picea abies L. [Karst]) twigs in the field - Results of a dynamic enclosure study, Atmos. Environ., 40, Supplement 1, 128-137, 2006.

Greenberg, J. P., Guenther, A., Zimmerman, P., Baugh, W., Geron, C., Davis, K., Helmig, D., and Klinger, L. F.: Tethered balloon measurements of biogenic VOCs in the atmospheric boundary layer, Atmos. Environ., 33, 855-867, 1999a.

Greenberg, J. P., Guenther, A., Madronich, S., and Baugh, W.: Biogenic volatile organic compound emissions in central Africa during the Experiment for the Regional Sources and Sinks of Oxidants (EXPRESSO) biomass burning season, J. Geophys. Res., 104, 30659-30671, 1999b.

Greenberg, J. P., Guenther, A., Pètron, G., Wiedinmyer, C., Vega, O., Gatti, L. V., Tota, J., and Fisch, G.: Biogenic VOC emissions from forested Amazonian landscapes, Global Change Biol., 10, 651-662, 2004.

Guenther, A.: The contribution of reactive carbon emissions from vegetation to the carbon balance of terrestrial ecosystems, Chemosphere, 49, 837-844, 2002. 
Guenther, A., Hewitt, N. C., Erickson, D., Fall, R., Geron, C., Graedel, T., Harley, P., Klinger, L., Lerdau, M., McKay, W. A., Pierce, T., Scholes, B., Steinbrecher, R., Taalamraju, R., Taylor, J., ad Zimmermann, P.: A global model of natural volatile organic compound emissions, J. Geophys. Res., 100, 8873-8892, 1995.

Guenther, A., Greenberg, J., Harley, P., Helmig, D., Klinger, L., Vierling, L., Zimmerman, P., and Geron, C.: Leaf, branch, stand, and landscape scale measurements of natural volatile organic compounds, Tree Physiol., 16, 17-24, 1996.

Guenther, A., Karl, T., Harley, P., Wiedinmyer, C., Palmer, P. I., and Geron, C.: Estimates of global terrestrial isoprene emissions using MEGAN (Model of Emissions of Gases and Aerosols from Nature), Atmos. Chem. Phys., 6, 3181-3210, doi:10.5194/acp-63181-2006, 2006.

Guiochon, G.: Retention indices in programmed temperature gas chromatography, Anal. Chem., 36, 661-663, 1964.

Haagen-Smit, A. J.: Chemistry and physiology of Los Angeles smog, Ind. Eng. Chem., 44, 1342-1346, 1952.

Haapanala, S., Ekberg, A., Hakola, H., Tarvainen, V., Rinne, J., Hellén, H., and Arneth, A.: Mountain birch - potentially large source of sesquiterpenes into high latitude atmosphere, Biogeosciences, 6, 2709-2718, doi:10.5194/bg-6-2709-2009, 2009.

Hakola, H., Tarvainen, V., Bäck, J., Ranta, H., Bonn, B., Rinne, J., and Kulmala, M.: Seasonal variation of mono- and sesquiterpene emission rates of Scots pine, Biogeosciences, 3, 93-101, doi:10.5194/bg-3-93-2006, 2006.

Hamilton, J. F., Webb, P. J., Lewis, A. C., Hopkins, J. R., Smith, S., and Davy, P.: Partially oxidised organic components in urban aerosol using GCXGC-TOF/MS, Atmos. Chem. Phys., 4, 12791290, doi:10.5194/acp-4-1279-2004, 2004.

Heiden, A. C., Kobel, K., Langebartels, C., Schuh-Thomas, G., and Wildt, J. J.: Emissions of oxygenated volatile organic compounds from plants, Part I: Emissions from lipoxygenase activity atmospheric chemistry, J. Atmos. Chem., 45, 143-172, 2003.

Heil, M. and Ton, J.: Long-distance signalling in plant defence, Trends Plant Sci., 13, 264-272, 2008.

Helmig, D.: Ozone removal techniques in the sampling of atmospheric volatile organic trace gases, Atmos. Environ., 31, 36353651, 1997.

Helmig, D. and Greenberg, J. P.: Automated in-situ gaschromatographic mass-spectrometric analysis of ppt level organic trace gases using multistage solid-adsorbent trapping, J. Chromatogr. A, 676, 389-398, 1994.

Helmig, D. and Vierling, L.: Water adsorption capacity of the solid adsorbents Tenax TA, Tenax GR, Carbotrap, Carbotrap C, Carbosieve SIII, and Carboxen 569 and water management techniques for the atmospheric sampling of volatile organic trace gases, Anal. Chem., 67, 4380-4386, 1995.

Helmig, D., Greenberg, J., Guenther, A., Zimmerman, P., and Geron, C.: Volatile organic compounds and isoprene oxidation products at a temperate deciduous forest site, J. Geophys. Res., 103, 22397-22414, 1998.

Helmig, D., Ortega, J., Duhl, T., Tanner, D., Guenther, A., Harley, P., Wiedinmyer, C., Milford, J., and Sakulyanontvittaya, T.: Sesquiterpene emissions from pine trees-identifications, emission rates and flux estimates for the contiguous United States, Environ. Sci. Technol., 41, 1545-1553, 2007.
Heuskin, S., Lorge, S., Godin, B., Leroy, P., Frere, I., Verheggen, F., Haubruge, E., Wathelet, J.-P., Mestdagh, M., Hance, T., and Lognay, G.: Optimisation of a semiochemical slow-release alginate formulation attractive towards Aphidius ervi Haliday parasitoids, Pest. Manag. Sci., 68, 127-136, doi:10.1002/ps2234, 2012.

Hoffmann, T.: Adsorptive preconcentration technique including oxidant scavenging for the measurement of reactive natural hydrocarbons in ambient air, Fresen. J. Anal. Chem., 351, 41-47, 1995.

Jardine, K., Abrell, L., Kurc, S. A., Huxman, T., Ortega, J., and Guenther, A.: Volatile organic compound emissions from Larrea tridentata (creosotebush), Atmos. Chem. Phys., 10, 1219112206, doi:10.5194/acp-10-12191-2010, 2010.

Kännaste, A., Vongvanich, N., and Borg-Karlson, A.-K.: Infestation by a Nalepella species induces emissions of $\alpha$ - and $\beta$ farnesenes, (-)-linalool and aromatic compounds in Norway spruce clones of different susceptibility to the large pine weevil, Arthrop.-Plant Interact., 2, 31-41, 2008.

Kaplan, J. O., Folberth, G., and Hauglustaine, D. A.: Role of methane and biogenic volatile organic compound sources in late glacial and Holocene fluctuations of atmospheric methane concentrations, Global Biogeochem. Cy., 20, GB2016, doi:10.1029/2005GB002590, 2006.

Karl, T., Guenther, A., Jordan, A., Fall, R., and Lindinger, W.: Eddy covariance measurement of biogenic oxygenated VOC emissions from hay harvesting, Atmos. Environ., 35, 491-495, 2001.

Karl, T., Guenther, A., Turnipseed, A., Patton, E. G., and Jardine, K.: Chemical sensing of plant stress at the ecosystem scale, Biogeosciences, 5, 1287-1294, doi:10.5194/bg-5-1287-2008, 2008.

Komenda, M., Parusel, E., Wedel, A., and Koppmann, R.: Measurements of biogenic VOC emissions: sampling, analysis and calibration, Atmos. Environ., 35, 2069-2080, 2001.

Komenda, M., Schaub, A., and Koppmann, R.: Description and characterization of an on-line system for long-term measurements of isoprene, methyl vinyl ketone, and methacrolein in ambient air, J. Chromatogr. A, 995, 185-201, 2003.

Langford, B., Misztal, P. K., Nemitz, E., Davison, B., Helfter, C., Pugh, T. A. M., MacKenzie, A. R., Lim, S. F., and Hewitt, C. N.: Fluxes and concentrations of volatile organic compounds from a South-East Asian tropical rainforest, Atmos. Chem. Phys., 10, 8391-8412, doi:10.5194/acp-10-8391-2010, 2010.

Lelieveld, J., Butler, T. M., Crowley, J. N., Dillon, T. J., Fischer, H., Ganzeveld, L., Harder, H., Lawrence, M. G., Martinez, M., Taraborrelli, D., and Williams, J.: Atmospheric oxidation capacity sustained by a tropical forest, Nature, 452, 737-740, 2008.

Mielke, L. H., Pratt, K. A., Shepson, P. B., McLuckey, S. A., Wisthaler, A., and Hansel, A.: Quantitative determination of biogenic volatile organic compounds in the atmosphere using proton-transfer reaction linear ion trap mass spectrometry, Anal. Chem., 82, 7952-7957, 2010.

Misztal, P. K., Owen, S. M., Guenther, A. B., Rasmussen, R., Geron, C., Harley, P., Phillips, G. J., Ryan, A., Edwards, D. P., Hewitt, C. N., Nemitz, E., Siong, J., Heal, M. R., and Cape, J. N.: Large estragole fluxes from oil palms in Borneo, Atmos. Chem. Phys., 10, 4343-4358, doi:10.5194/acp-10-4343-2010, 2010.

Muller, J. F.: Geographical-distribution and seasonal-variation of surface meissions and deposition velocities of atmospheric trace gases, J. Geophys. Res., 97, 3787-3804, 1992. 
Ormeno, E., Gentner, D., Fares, S., Karlik, J., Park, J., and Goldstein, A.: Sesquiterpenoid emissions from agricultural crops: Correlations to monoterpenoid emissions and leaf terpene content, Environ. Sci. Technol., 44, 3758-3764, 2010.

Ortega, J. and Helmig, D.: Approaches for quantifying reactive and low-volatility biogenic organic compound emissions by vegetation enclosure techniques - Part A, Chemosphere, 72, 343-364, 2008.

Ortega, J., Helmig, D., Guenther, A., Harley, P., Pressley, S., and Vogel, C.: Flux estimates and $\mathrm{OH}$ reaction potential of reactive biogenic volatile organic compounds (BVOCs) from a mixed northern hardwood forest, Atmos. Environ., 41, 54795495, 2007.

Pankow, J. F.: Effects of trapping temperature and film thickness in purge and trap with whole column cryotrapping on fused silica columns, J. High Resol. Chromatogr. Commun., 9, 18-29, 1986.

Pankow, J. F., Luo, W., Isabelle, L. M., Bender, D. A., and Baker, R. J.: Determination of a wide range of volatile organic compounds in ambient air using multisorbent adsorption/thermal desorption and gas chromatography/mass spectrometry, Anal. Chem., 70, 5213-5221, 1998.

Pankow, J. F., Luo, W., Bender, D. A., Isabelle, L. M., Hollingsworth, J. S., Chen, C., Asher, W. E., and Zogorski, J. S.: Concentrations and co-occurrence correlations of 88 volatile organic compounds (VOCs) in the ambient air of 13 semi-rural to urban locations in the United States, Atmos. Environ., 37, 50235046, 2003.

Papiez, M., Potosnak, M., Goliff, W., Guenther, A., Matsunaga, S., and Stockwell, W.: The impacts of reactive terpene emissions from plants on air quality in Las Vegas, Nevada, Atmos. Environ., 43, 4109-4123, 2009.

Penuelas, J. and Staudt, M.: BVOCs and global change, Trends Plant Sci., 15, 133-144, 2010.

Piccot, S. D., Watson, J. J., and Jones, J. W.: A global inventory of volatile organic-compound emissions from anthropogenic sources, J. Geophys. Res., 97, 9897-9912, 1992.

Pöschl, U., Martin, S. T., Sinha, B., Chen, Q., Gunthe, S. S., Huffman, J. A., Borrmann, S., Farmer, D. K., Garland, R. M., Helas, G., Jimenez, J. L., King, S. M., Mikhailov, E., Pauliquevis, T., Petters, M. D., Prenni, A. J., Roldin, P., Rose, J., Schneider, J., Su, H., Zorn, S. R., Artaxo, P., and Andreae, M. O.: Rainforest aerosols as biogenic nuclei of clouds and precipitation in the Amazon, Science, 329, 1513-1516, 2010.

Pollmann, J., Ortega, J., and Helmig, D.: Analysis of atmospheric sesquiterpenes: Sampling losses and mitigation of ozone interferences, Environ. Sci. Technol., 39, 9620-9629, 2005.

Pressley, S., Lamb, B., Westberg, H., Guenther, A., Chen, J., and Allwine, E.: Monoterpene emissions from a Pacific Northwest old-growth forest and impact on regional biogenic VOC emission estimates, Atmos. Environ., 38, 3089-3098, 2004.

Purves, D. W., Caspersen, J. P., Moorcroft, P. R., Hurtt, G. C., and Pacala, S. W.: Human-induced changes in US biogenic volatile organic compound emissions: evidence from long-term forest inventory data, Global Change Biol., 10, 1737-1755, 2004.

Rosenstiel, T. N., Potosnak, M. J., Griffin, K. L., Fall, R., and Monson, R. K.: Increased $\mathrm{CO}_{2}$ uncouples growth from isoprene emission in an agriforest ecosystem, Nature, 421, 256-259, 2003.
Sartin, J. H., Halsall, C. J., Davison, B., Owen, S., and Hewitt, C. N.: Determination of biogenic volatile organic compounds (C8-C16) in the coastal atmosphere at Mace Head, Ireland, Anal. Chim. Acta, 428, 61-72, 2001.

Saxton, J. E., Lewis, A. C., Kettlewell, J. H., Ozel, M. Z., Gogus, F., Boni, Y., Korogone, S. O. U., and Serça, D.: Isoprene and monoterpene measurements in a secondary forest in northern Benin, Atmos. Chem. Phys., 7, 4095-4106, doi:10.5194/acp-74095-2007, 2007.

Singsaas, E. L. and Sharkey, T. D.: The effects of high temperature on isoprene synthesis in oak leaves, Plant Cell Environ., 23, 751757, 2000.

Starn, T. K., Shepson, P. B., Bertman, S. B., White, J. S., Splawn, B. G., Riemer, D. D., Zika, R. G., and Olszyna, K.: Observations of isoprene chemistry and its role in ozone production at a semirural site during the 1995 Southern Oxidants Study, J. Geophys.Res. 103, 22425-22435, 1998.

Staudt, M. and Bertin, N.: Light and temperature dependency of the emission of cyclic and acyclic monoterpenes from Holm oak (Quercus ilex L.) leaves, Plant Cell Environ., 21, 385-395, 1998.

Tan, D., Faloona, I., Simpas, J. B., Brune, W., Shepson, P. B., Couch, T. L., Sumner, A. L., Carroll, M. A., Thornberry, T., Apel, E., Riemer, D., and Stockwell, W.: Results from the PROPHET summer 1998 campaign, J. Geophys. Res., 106, 24407-24427, 2001.

Tsui, J. K.-Y., Guenther, A., Yip, W.-K., and Chen, F.: A biogenic volatile organic compound emission inventory for Hong Kong, Atmos. Environ., 43, 6442-6448, 2009.

US Environmental Protection Agency: Compendium Method TO14A, Determination of Volatile Organic Compounds (VOCs) in Ambient Air Using Specially Prepared Canisters With Subsequent Analysis by Gas Chromatography, Center for Environmental Research Information, Office of Research and Development, US Environmental Protection Agency, EPA/625/R-96/010b, http://www.epa.gov/ttnamti1/files/ambient/airtox/to-14ar.pdf, last access: 24 January 2012, Cincinnati, OH 45268, January 1999a.

US Environmental Protection Agency: Compendium Method TO-15, Determination of Volatile Organic Compounds (VOCs) in Air Collected in Specially-Prepared Canisters and Analyzed by Gas Chromatography/Mass Spectrometry (GC/MS), Center for Environmental Research Information, Office of Research and Development, US Environmental Protection Agency, EPA/625/R-96/010b, http://www.epa.gov/ttnamti1/files/ambient/airtox/to-15r.pdf, last access: 24 January 2012, Cincinnati, OH 45268, January 1999 b.

Valdés, D. M., Martinez, J. R., and Stashenko, E. E.: HRGC-MS analysis of essential oils in five species of the Myrtaceae family grown in Colombia, Presented at the International Congress of Analytical Sciences, Moscow, Russia, 2006.

Welthagen, W., Shellie, R. A., Spranger, J., Ristow, M., Zimmermann, R., and Fiehn, O.: Comprehensive two-dimensional gas chromatography-time-of-flight mass spectrometry $(\mathrm{GC} \times \mathrm{GC}$ TOF) for high resolution metabolomics: biomarker discovery on spleen tissue extracts of obese NZO compared to lean C57BL/6 mice, Metabolomics, 1, 65-73, 2005. 
Williams, J., Roberts, J. M., Fehsenfeld, F. C., Bertman, S. B., Buhr, M. P., Goldan, P. D., Hübler, G., Kuster, W. C., Ryerson, T. B., Trainer, M., and Young, V.: Regional ozone from biogenic hydrocarbons deduced from airborne measurements of PAN, PPN, and MPAN, Geophys. Res. Lett., 24, 1099-1102, 1997.

Williams, J., Yassaa, N., Bartenbach, S., and Lelieveld, J.: Mirror image hydrocarbons from Tropical and Boreal forests, Atmos. Chem. Phys., 7, 973-980, doi:10.5194/acp-7-973-2007, 2007.
Yassaa, N., Custer, T., Song, W., Pech, F., Kesselmeier, J., and Williams, J.: Quantitative and enantioselective analysis of monoterpenes from plant chambers and in ambient air using SPME, Atmos. Meas. Tech., 3, 1615-1627, doi:10.5194/amt-31615-2010, 2010. 